\title{
PENGARUH PROMOSI KESEHATAN DALAM PERAN PEMBERI ASI EKSLUSIF DI WILAYAH KERJA PUSKESMAS ARCAMANIK
}

\author{
Oktarian Pratama \\ Program Studi Diploma Tiga Keperawatan STIKes Dharma Husada \\ ian.pratama09@gmail.com
}

\begin{abstract}
ABSTRAK
Target nasional pemberian ASI Eksklusif di Indonesia itu $80 \%$, akan tetapi data ASI Eksklusif di Kota Bandung tahun 2017 sebanyak 27.291 bayi umur 0-6 bulan yang diberikan ASI Eksklusif hanya $67,3 \%$. Ketidak siapan ibu hamil diakibatkan karena kurangnya pengetahuan tentang ASI Eksklusif. Penelitian ini bertujuan untuk mengidentifikasi efektivitas kesiapan penyuluhan kesehatan antara kelompok intervensi dan kelompok kontrol mengenai pemberian ASI Eksklusif di wilayah kerja Puskesmas Arcamanik Kota Bandung. Jenis penelitian ini menggunakan Quasi eksperimen dengan bentuk desain Pretest-Posttest with Control Group. Dengan populasi 30 orang ibu hamil trimester III. Data penelitian dilakukan menggunakan kuesioner dengan skala likert dan skala dikotomi jumlah kuesioner 25. Hasil penelitian yang dilakukan kepada kelompok sebelum dan sesudah penyuluhan menggunakan uji Paired T-Test diperoleh p-value $=0,000<0,05$. Berdasarkan hasil penelitian menunjukan adanya efektivitas penyuluhan kesehatan "POSFLIP ASI" terhadap kesiapan ibu dalam pemberian ASI Eksklusif di wilayah kerja Puskesmas Arcamanik Kota Bandung. Saran bagi puskesmas agar selalu melakukan edukasi baik kepada ibu hamil ataupun ibu menyusui.
\end{abstract}

Kata Kunci :, Pemberi ASI Ekslusif, Promosi Kesehatan

\section{PENDAHULUAN}

Masalah kesehatan anak merupakan salah satu masalah utama dalam bidang kesehatan di Indonesia. Angka kematian bayi (AKB) pada tahun 2016 sebesar 3,93/1000 kelahiran hidup, angka ini menurun 0,16 poin dibanding tahun 2015 sebesar 4,09/1000 kelahiran hidup. Angka kematian bayi berasal dari bayi usia 028 hari (Neonatal) sebesar $84,63 \%$ atau 3,32/1000 kelahiran hidup. Angka kematian bayi di Jawa Barat sebesar 3,93/1000 kelahiran hidup, sudah mencapai target MDGs pada tahun 2015 yang sudah mencapai 17/1000 kelahiran hidup (Dinkes Jabar, 2016).
Menurut World Health Organization (WHO, 2013), empat penyebab utama kematian pada balita di dunia yaitu $18 \%$ pneumonia, $16 \%$ prematuritas $(14 \%$ selama periode neonatal dan $2 \%$ dalam periode pasca neonatal), $11 \%$ penyakit diare dan $10 \%$ asfiksia lahir (9\% selama periode neonatal dan $1 \%$ dalam periode pasca-neonatal). Faktor utama yang menyebabkan tingginya angka kematian bayi diantaranya sepsis, kelainan bawaan, infeksi saluran pernapasan atas, lingkungan, dan faktor nurisi. Karena sumber nutrisi alamiah yang memiliki kandungan gizi dan merupakan makanan yang paling sempurna adalah Air Susu Ibu (ASI) (Depkes RI, 2012). 
Terkait dengan faktor-faktor lain terutama nutrisi gizi. Gizi yang baik untuk bayi adalah ASI yang mengandung sumber gizi yang sempurna untuk pertembuhan dan perkembangan bayi (Astuti dkk, 2015).

Berdasarkan Peraturan Pemerintah Nomor 33 Tahun 2012 Air Susu Ibu (ASI) Eksklusif adalah ASI yang diberikan kepada bayi sejak dilahirkan selama enam bulan, tanpa menambahkan dan/atau mengganti dengan makanan atau minuman lain (kecuali obat, vitamin dan mineral) (Profil Kesehatan Indonesia, 2017). Air Susu Ibu (ASI) mempunyai kandungan emulsi lemak dalam larutan protein, laktosa dan garam-garam organik yang disekresi oleh kedua belah kelenjar payudara ibu, sebagai makanan utama bagi bayi. Berdasarkan World Health Organization (2014), persentase bayi yang diberikan ASI Eksklusif 0-6 bulan di seluruh dunia hanya sebesar $38 \%$ yang berarti 3 dari 5 bayi usia 6 bulan tidak mendapatkan ASI Eksklusif.

Menurut Kemenkes RI 2014, menyatakan bahwa persentase pemberian ASI Eksklusif pada bayi 0-6 bulan di Indonesia tahun 2012 yaitu sebesar 48,6\%. Sedangkan pada tahun 2013 yaitu sebesar 54,3\% sedikit mengalami peningkatan dibandingkan tahun sebelumnya. Walaupun sudah mengalami peningkatan, namun angka tersebut masih dibawah target nasional yang diharapkan dalam mencapai tujuan peningkatan pemberian ASI Eksklusif yang seharusnya mencapai angka $80 \%$.
Berdasarkan Riskesdas, persentase pemberian ASI Eksklusif di Indonesia tahun 2013 pada bayi usia 0 bulan sebanyak $(52,7 \%)$ ,satu bulan $(48,7 \%)$, dua bulan (46\%), tiga bulan $(42,2 \%)$, empat bulan $(41,9 \%)$, lima bulan (36,6\%), dan enam bulan $(30,2 \%)$. Pemberian ASI Eksklusif di Jawa Barat (2016 ) sebanyak 349.968 bayi umur 0-6 bulan dari 754.438 jumlah bayi $0-6$ bulan $(46,4 \%)$ gambaran ini masih dibawah cakupan nasional $52,3 \%$ terlebih target nasional sebesar $80 \%$, (Dinkes Jawa Barat, 2016). Pemberian ASI Eksklusif di Kota Bandung pada tahun 2017 sebanyak 27.291 bayi umur 0-6 bulan dengan cakupan pemberian ASI Eksklusif 67,3\%, gambaran ini masih di bawah target nasional yaitu 80\% (Laporan Bulanan Gizi, 2017). Akan tetapi yang terjadi di Puskesmas Arcamanik Kota Bandung cakupan pemberian ASI Eksklusif hanya masih rendah dengan target ASI di Puskesmas Arcamanik Kota Bandung adalah 50\% untuk tahun 2019. Berdasarkan data tersebut dilihat terjadi penurunan pemberian ASI Eksklusif seiring dengan berjalannya usia anak.

Faktor-faktor yang mempengaruhi pemberian ASI Eksklusif yang pertama adalah karena kurangnya pengetahuan ibu tentang ASI Eksklusif (32\%) yaitu ibu-ibu menghentikan pemberian ASI karena produksi ASI kurang (Marzida, 2016). Akibat pada bayi yang tidak diberikan ASI Eksklusif dan sudah diberi makanan pendamping sebelum berusia 6 bulan yaitu bayi akan mengalami penyakit infeksi misalnya, diare, ISPA, infeksi telinga 
JURNAL SEHAT MASADA VOLUME XIV NOMOR 1 Januari 2020 ISSN : 1979-2344

dan kekurangan gizi. Sedangkan akibat pada ibu adalah akan terjadi bendungan ASI, payudara ibu bengkak, dan mastitis (Prasetyono, 2009).

Meskipun pemberian ASI Eksklusif telah banyak disosialisasikan. Beberapa anggapan keliru sering kali mengenyampingkan kebutuhan nutrisi bayi. Selain itu, keberhasilan media promosi dapat berpengaruh terhadap pola pikir para ibu bahwa susu formula yang banyak mengandung DHA, AA dan kandungan lain lebih cocok dan sangat dibutuhkan oleh bayi ketimbang ASI. Rendahnya tingkat pemahaman tentang pentingnya ASI selama 6 bulan pertama kelahiran bayi dikarenakan kurangnya informasi dan pengetahuan yang dimiliki oleh para ibu mengenai segala nilai plus nutrisi dan manfaat yang terkandung dalam ASI (Prasetyono, 2009).

Jikalau penyuluhan kesehatan adalah kegiatan pendidikan yng dilakukan dengan cara menyebarkan pesan, menanamkan keyakinan, sehingga masyarakat tidak saja sadara, tahu atau mengerti, tetapi juga malu dan bisa melakukan suatu anjuran yang ada hubungannya dengan kesehatan (Notoatmodjo, 2012). WHO merumuskan bahwa promosi kesehatan sebagai proses untuk meningkatkan kemampuan masyarakat dalam memelihara dan meningkatkan kesehatannya. Terdapat beberapa media dalam melakukan penyuluhan atau promosi kesehatan yaitu media cetak, media elektronik dan media papan (Fitriani,2011).
Media cetak seperti leaflet, booklet, flipchart (lembar balik), poster. Poster biasanya ditempelkan pada suatu tempat yang mudah dilihat dan banyak dilalui orang misalnya di dinding balai desa, pinggir jalan, papang pengumuman dan lain-lain. Gambar dalam poster dapat berupa lukisan, ilustrasi, kartun, gambar atau photo. Poster terutama dibuat untuk memikat orang banyak, memberikan pesan singkat. Karena itu cara pembuatannya harus menarik, sederhana dan hanya berisikan satu ide atau satu kenyataan saja. Poster yang baik adalah poster yang mempunyai daya tinggal lama dalam ingatan orang yang melihatnya serta dapat mendorong untuk bertindak (Notoatmodjo, 2010). Flipchart (lembaran balik) akan memudahkan pekerjaan untuk menerangkan dan memberikan informasi dengan gambar tahap demi tahap. Setiap tahapan memiliki satu gambar yang bernomor setelah selesai maka lembaran gambar tersebut dibalikan begitu seterusnya hingga akhir. Kelebihan lembar balik adalah gambar yang jelas dan dapat dilihat secara bersama-sama, menarik dan mudah dimengerti. (Notoatmodjo, 2012).

Media elektronik seperti televisi, film atau video dan radio. Media film atau video merupakan media yang dapat menyajikan pesan yang bersifat fakta atau fiktif yang dapat bersifat informatif, edukatif maupun instruksional Film atau video dapat mengatasi kekurangan keterampilan dalam membaca dan penguasaan bahasa, mengatasi keterbatasan penglihatan (Fitriani,2011). 
Puskesmas Arcamanik mempunyai beberapa program diantaranya, basic six (promosi kesehatan, kesehatan lingkungan, kesehatan keluarga dan reproduksi, perbaikan gizi, pemberantasan penyakit menular dan penyembuhan penyakit serta pelayanan kesehatan). Dari hasil penelitian terdahulu oleh Suhertusi, Desmiwarsi \& Nurjasmi (2014) menunjukkan hasil bahwa promosi kesehatan dengan media leaflet dan film terdapat peningkatan pengetahuan sebelum dan sesudah diberikan promosi kesehatan dan dengan media film lebih efektif meningkatkan pengetahuan. Menurut hasil penelitian terdahulu oleh Apriliana (2016) menunjukkan hasil bahwa ada pendidikan kesehatan dengan metode ceramah hingga tingkat pengetahuan dan sikap pemberian ASI Eksklusif untuk ibu hamil primigravida di Puskesmas Kapuan Tahun 2016. Menurut hasil penelitian terdahulu oleh (Marzida, 2016) menunjukan hasil yang sangat siap memberikan ASI Eksklusif berjumlah 2 ibu hamil $(3,3 \%)$, siap berjumlah 43 ibu hamil $(71,7 \%)$, tidak siap berjumlah 15 ibu hamil $(25,0 \%)$ dan yang sangat tidak siap memberikan ASI Eksklusif berjumlah 0 ibu hamil (0\%).

Dari hasil studi pendahuluan Puskesmas Arcamanik Kota Bandung untuk cakupan ASI Eksklusif masih rendah, upaya dari puskesmas sudah dilakukan penyuluhan kepada ibu menyusui menggunakan media leaflet dan sudah melakukan konseling di wilayah kerja puskesmas, namun gambaran dari hasil konseling adalah ibu mengatakan ASI tidak keluar, kuantitas ASI yang kurang, sudah dikasih susu formula sejak lahir ketika ibunya di operasi, dan ibunya bekerja serta belum dilakukannya evaluasi dari penyuluhan mengenai ASI Eksklusif. Dari hasil wawancara 5 ibu hamil diantara 3 ibu ASI nya sudah ada yang keluar, 3 diantaranya belum mengetahui mengenai ASI Eksklusif, ibu hanya mengetahui bahwa pemberian ASI Eksklusif diberikan selama 2 tahun, ibu tidak mengetahui kandungan dari ASI, teknik dan posisi menyusi yang benarpun masih ada yang belum tahu, tujuan dan motif pemberian ASI ibu belum mengetahui, ibu hanya mengetahui manfaat ASI bagi bayinya saja sedangkan manfaat untuk ibunya tidak mengetahui.

Hal tersebut diperkuat dengan data dari puskesmas bulan Februari 2019 bahwa jumlah 90 bayi hanya 2 orang $(0,02 \%)$ yang lulus ASI Eksklusif selama 6 bulan selebihnya para ibu memberikan susu formula. Target ASI Eksklusif di wilayah kerja Puskesma Arcamanik Kota Bandung pada tahun 2019 adalah 50\%. Ada program tambahan yaitu, UKS, kesehatan olahraga, kesehatan lansia, kesehatan jiwa, kesehatan mata, kesehatan gigi, laboratorium sederhana dan perkesmas (PKM Arcamanik Kota Bandung).

Dari uraian diatas penelti perlu untuk melakukan penelitian dengan menggunakan poster dan flipchart yang disebut "POSFLIP ASI" mengenai "Efektivitas Penyuluhan Kesehatan "POSFLIP ASI" Terhadap 
Kesiapan Ibu Hamil Dalam Pemberian ASI

Eksklusif. POSFLIP ASI merupakan penyuluhan kesehatan dengan menggunakan poster dan flipchart sebagai media penyuluhan air susu ibu. Adapun alasan peneliti memilih judul tersebut karena angka cakupan pemberian ASI Ekslusif masih rendah, ketidaktahuan ibu mengenai manfaat dan kandungan ASI dan belum pernah dilakukan evaluasi dari penyuluhan.

\section{METODE PENELITIAN}

Penelitian yang digunakan adalah penelitian Quasi eksperimen dengan bentuk desain Pretest-Posttest with Control Group untuk mengetahui efektivitas penyuluhan kesehatan "POSFLIP ASI" Terhadap Kesiapan Ibu Hamil Dalam Pemberian ASI Eksklusif Di Wilayah Kerja Puskesmas Arcamanik Kota Bandung. Metode ini merupakan metode penelitian dengan dilakukan pretest (01) pada kedua kelompok tersebut (kelompok kontrol dan intervensi) dan diikuti penyuluhan kesehatan pada kelompok intervensi. Setelah beberapa waktu dilakukan posttest (02) pada kedua kelompok tersebut.

Populasi dalam penelitian ini adalah ibu hamil trimester 3 yang berjumlah 33 orang di wilayah kerja Puskesmas Arcamanik Kota Bandung dan Teknik sampling yang digunakan adalah Purposive Sampling, yaitu mengambil sampel dengan pertimbangan yang dibuat oleh peneliti sendiri berdasarkan ciri atau sifat-sifat populasi yang diketahui sebelumnya
(Notoatmodjo, 2010). Setelah dihitung dengan rumus didapatkan jumlah responden 30 orang.

\section{HASIL DAN PEMBAHASAN}

\section{HASIL}

1. Karakteristik Responden di Wilayah Kerja Puskesmas Arcamanik Kota Bandung

Tabel 1 Distribusi Frekuensi Karakteristik Responden di Wilayah Kerja Puskesmas Arcamanik Kota Bandung

\begin{tabular}{ccccc}
\hline \multirow{2}{*}{ Karakteristik } & \multicolumn{2}{c}{ Intervensi } & \multicolumn{2}{c}{ Kontrol } \\
& f & $\mathbf{\%}$ & $\mathbf{f}$ & $\mathbf{\%}$ \\
\hline Usia kehamilan & & & & \\
32 & 2 & 13,3 & 3 & 20 \\
34 & 3 & 20 & 4 & 26,7 \\
36 & 8 & 53,3 & 7 & 46,7 \\
38 & 2 & 13,4 & 1 & 6,6 \\
Total & $\mathbf{1 5}$ & $\mathbf{1 0 0}$ & $\mathbf{1 5}$ & $\mathbf{1 0 0}$ \\
\hline
\end{tabular}

2. Gambaran Kesiapan ibu hamil sebelum penyuluhan kesehatan "POSFLIP ASI" di Wilayah Kerja Puskesmas Arcamanik Kota Bandung

Tabel 2 Kesiapan ibu hamil sebelum penyuluhan kesehatan "POSFLIP ASI" di Wilayah Kerja Puskesmas Arcamanik Kota Bandung

\begin{tabular}{lcccc}
\hline Kesiapan & Mean & Min & Max & $\begin{array}{c}\text { Std. } \\
\text { Deviasi }\end{array}$ \\
\hline \multicolumn{1}{c}{ Sebelum } & & & & \\
$\begin{array}{l}\text { Kelompok } \\
\text { Kontrol }\end{array}$ & 54,53 & 44 & 63 & 4,596 \\
$\begin{array}{l}\text { Kelompok } \\
\text { Intervensi }\end{array}$ & 61,93 & 55 & 70 & 4,008 \\
\hline
\end{tabular}


3. Gambaran Kesiapan ibu hamil sesudah penyuluhan kesehatan "POSFLIP ASI" di Wilayah Kerja Puskesmas Arcamanik Kota Bandung

Tabel 3 Gambaran Kesiapan ibu hamil sesudah penyuluhan kesehatan "POSFLIP ASI" di Wilayah Kerja Puskesmas Arcamanik Kota Bandung

\begin{tabular}{lcccc}
\hline \multicolumn{1}{c}{ Kesiapan } & Mean & Min & Max & $\begin{array}{c}\text { Std. } \\
\text { Deviasi }\end{array}$ \\
\hline $\begin{array}{l}\text { Sesudah } \\
\text { Kelompok } \\
\text { Kontrol }\end{array}$ & 63,60 & 53 & 70 & 4,323 \\
$\begin{array}{l}\text { Kelompok } \\
\text { Intervensi }\end{array}$ & 72,07 & 65 & 80 & 4,682 \\
\hline
\end{tabular}

4. Hasil Perbedaan kesiapan sebelum dan sesudah Pada Kelompok Dan Intervensi Kelompok Kontrol

Tabel 4 Perbedaan kesiapan sebelum dan sesudah Pada Kelompok dan Intervensi Kelompok Kontrol

\begin{tabular}{lcccc}
\hline Kesiapan & $\mathbf{N}$ & Rerata & SD & p-value \\
\hline Intervensi & & & & \\
Pre & 15 & 61,93 & 4,008 & 0,000 \\
Post & 15 & 72,07 & 4,682 & \\
\hline Kesiapan & $\mathbf{N}$ & Rerata & SD & p-value \\
\hline Kontrol & & & & \\
Pre & 15 & 54,53 & 4,596 & 0,000 \\
Post & 15 & 63,60 & 4,323 & \\
\hline
\end{tabular}

5.Efektivitas penyuluhan kesehatan "POSFLIP ASI" pada kelompok intervensi dan kelompok kontrol

Tabel 5 Efektivitas penyuluhan kesehatan "POSFLIP ASI" pada kelompok intervensi dan kelompok kontrol

\begin{tabular}{lclll}
\hline Kesiapan & N & Rerata & Std. Deviasi & $\begin{array}{l}\boldsymbol{p} \text { - } \\
\text { value }\end{array}$ \\
\hline $\begin{array}{l}\text { Kelompok } \\
\begin{array}{l}\text { Intervensi } \\
\text { Kelompok }\end{array}\end{array}$ & 15 & 10,13 & 4,373 & \\
Kontrol & 9,07 & 3,555 & 0,417 \\
\hline
\end{tabular}

\section{PEMBAHASAN}

Penelitian bertujuan untuk mengetahui bagaimana efektivitas penyuluhan kesehatan "POSFLIP ASI" terhadap kesiapan ibu hamil dalam pemberian ASI Eksklusif di wilayah kerja Puskesmas Arcamanik Kota Bandung. Penelitian ini dilakukan pada bulan JuliAgustus 2019 dengan sampel 33 ibu hamil primipara dengan usia kandung trimester III ( > 32 minggu ) wilayah kerja Puskesmas Arcamanik Kota Bandung. Berikut penjelasan mengenai hasil penelitian yang terdiri dari gambaran kesiapan sebelum penyuluhan kesehatan, gambaran kesiapan sesudah penyuluhan kesehatan, perbedaan kesiapan pada kelompok kontrol dan kelompok intervensi dan perbedaan efektivitas penyuluhan kesehatan "POSFLIP ASI" terhadap kesiapan ibu hamil dalam pemberian ASI Eksklusif:

Berdasarkan hasil penelitian yang telah dilakukan di wilayah kerja Puskesmas Arcamanik Kota Bandung didapatkan data gambaran kesiapan sebelum di berikan penyuluhan kesehatan "POSFLIP ASI" pada kelompok intervensi sebagian besar dari responden memiliki kesiapan yang baik dengan nilai rata-rata-rata 61,93 sedangkan kelompok kontrol didapatkan rata-rata 54,53. Hal ini menunjukan bahwa seluruh ibu hamil memiliki kesiapan yang baik dalam pemberian ASI Eksklusif sebelum dilakukan penyuluhan kesehatan "POSFLIP ASI" (Poster Flipchart Air Susu Ibu). Pertanyaan kuesioner sebelum dilakukan penyuluhan kesehatan yang 
meningkat ada di pertanyaan kesiapan motif sebesar 48 (pre-test kontrol) dan pengetahuan sebesar 48 (pre-test intervensi).

Faktor-faktor yang mempengaruhi pemberian ASI eksklusif dibedakan menjadi tiga, yaitu faktor pemudah (predisposing factors) meliputi pendidikan, pengetahuan, adat budaya, persiapan ASI eksklusif pada masa kehamilan. Faktor pendukung (enabling factors) meliputi pendapatan keluarga, ketersediaan waktu, kesehatan ibu. Faktor pendorong (reinforcing factors) meliputi dukungan keluarga, dukungan petugas kesehatan (Green dalam Haryono dan Setianingsih, 2014).

\section{Menurut Notoadmojo (2010),} pengetahuan merupakan hasil dari tahu dan terjadi setelah orang melakukan penginderaan terhadap obyek tertentu. Pengetahuan dapat membentuk keyakinan tertentu sehingga seseorang berprilaku sesuai keyakinan (Notoadmodjo, 2010). Pernyataan diatas sesuai dengan teori menurut Nurhidayah (2009) yang memberikan pengertian tingkat kemampuan tahu yaitu kemampuan responden untuk menghafal, mengingat, mendefinisi, mengenali, atau mengidentifikasi informasi tentang fakta, peraturan, prinsip, kondisi dan syarat yang disajikan dalam pengajaran. Hal ini diharapkan ibu hamil dapat mengetahui tentang ASI Eksklusif sebelum menyusui, sehingga nutrisi bayi akan terpenuhi. Adanya kesiapan pengetahuan dan keterampil membuat ibu tahu apa yang terdapat dalam Air Susu Ibu serta bagaimana cara atau teknik dan posisi dalam menyusui.

Motif berasal dari dalam diri sendiri yang berupa kesadaran dan kemauan maupun dari luar yaitu keluarga, masyarakat dan tenaga kesehatan yang berupa pemberian informasi. Ibu yang memiliki motivasi rendah cenderung tidak memberikan ASI karena kurangnya motivasi dari dalam diri maupun dari luar. Sedangkan ibu yang memiliki motivasi tinggi, sebagian besar memberikan ASI secara eksklusif karena ibu sadar akan manfaat dan keuntungan ASI bagi ibu maupun bayinya. Motif dalam pemberian ASI Eksklusif sangat penting, karena motif salah satunya faktor yang mempengaruhi dalam pemberian ASI Eksklusif adanya motif atau dorongan dari diri sendiri ataupun orang lain ibu berkeinginan memberikan nutrisinya kepada bayi secara penuh. Hal ini sesuai dengan penelitian Ratih dan Dian (2009) bahwa ada hubungan antara motivasi dengan pemberian ASI eksklusif

Sebagian besar ibu hamil dalam penelitian ini sebelum dilakukan intervensi memiliki kesiapan pengetahuan yang baik, karena sebagian sudah mengatahui dari petugas pelayanan kesehatan yang sering melakukan konseling, hanya saja belum pernah dilakukan evaluasi setelah konseling tersebut.semakin baik tingkat pengetahuan seseorang maka semakin siap dan mampu untuk memberikan ASI Eksklusif kepada bayinya. Adapun faktor yang mempengaruhi ASI Eksklusif yaitu faktor internal yang berasal dari dalam diri sendiri diantranya kurang pengetahuan yang 
terkait dengan menyusui, karena jika tidak memiliki pengetahuan yang baik ibu tidak tahu tentang ASI. Untuk faktor eksternal itu di pengaruhi oleh lingkungan, ketidak pahaman ibu mengenai kolostrum (Roesli, 2010).

Dalam Jurnal Kesehatan tentang kesiapan ibu hamil dalam pemberian ASI Eksklusif menjelaskan bahwa kesiapan seorang ibu salah satunya di pengaruhi oleh tingkat pengetahuan dalam pemberian ASI Eksklusif. Salah satu strategi untuk memperoleh perubahan perilaku adalah dengan pemberian informasi untuk meningkatkan pengetahuan dan kesiapan dengan pemberian informasi, sehingga menimbulkan kesadaran dan dapat dilakukan dengan penyuluhan (Notoatmodjo, 2012). Pengetahuan ibu tentang ASI eksklusif diperoleh dari hasil pendidikan ibu yang bersifat informal melalui pendidikan kesehatan, brosur dan bisa juga pemberian informasi dari tenaga kesehatan saat melakukan kunjungan ke posyandu (Fikawati, 2010).

Berdasarkan hasil penelitian yang telah dilakukan di wilayah kerja Puskesmas Arcamanik Kota Bandung didapatkan data gambaran kesiapan sesudah di berikan penyuluhan kesehatan "POSFLIP ASI" mengalami peningkatan baik kelompok intervensi maupun kelompok kontrol. Pada kelompok intervensi di dapatkan nilai rata-rata 72,07 hal ini menunjukan bahwa seluruh ibu hamil memiliki kesiapan yang baik dalam pemberian ASI Eksklusif sebelum dilakukan penyuluhan kesehatan "POSFLIP ASI" (Poster
Flipchart Air Susu Ibu) terjadinya peningkatan. Meningkatnya hasil kesiapan sebelum dan sesudah penyuluhan tersebut karena adanya pengetahuan, tujuan, motif dan keterampilan yang diberikan kepada responden berupa penyuluhan kesehatan poster flipchart Air Susu Ibu. Pertanyaan kuesioner sesudah dilakukan penyuluhan kesehatan yang meningkat ada di pertanyaan kesiapan pengetahuan sebesar 55 (post-test kontrol) dan pengetahuan sebesar 56 (post-test intervensi).

Penyuluhan kesehatan adalah kegiatan pendidikan yng dilakukan dengan cara menyebarkan pesan, menanamkan keyakinan, sehingga masyrakat tidak saja sadara, tahu atau mengerti, tetapi juga malu dan bisa melakukan suatu anjuran yang ada hubungannya dengan keseharan (Notoatmodjo, 2012). Kelebihan media poster bias ditempelkan pada suatu tempat yang mudah dilihat dan banyak dilalui orang misalnya di dinding balai desa, pinggir jalan, papang pengumuman dan lain-lain. Gambar dalam poster dapat berupa lukisan, ilustrasi, kartun, gambar atau photo. Poster terutama dibuat untuk memikat orang banyak, memberikan pesan singkat. Karena itu cara pembuatannya harus menarik, sederhana dan hanya berisikan satu ide atau satu kenyataan saja. Poster yang baik adalah poster yang mempunyai daya tinggal lama dalam ingatan orang yang melihatnya serta dapat mendorong untuk bertindak (Notoatmodjo, 2010). Kelemahan poster mudah rusak Flipchart (lembaran balik) akan memudahkan pekerjaan untuk menerangkan dan memberikan informasi 
dengan gambar tahap demi tahap. Setiap tahapan memiliki satu gambar yang bernomor setelah selesai maka lembaran gambar tersebut dibalikan begitu seterusnya hingga akhir. Kelebihan lembar balik adalah gambar yang jelas dan dapat dilihat secara bersama-sama, menarik dan mudah dimengerti (Notoatmodjo, 2012). Kelemahan lembar balik jika tidak ada tempet untuk menyimpan medianya, maka akan sulit untuk dibaca.

Kesiapan pemberian ASI Eksklusif meliputi kondisi ibu hamil yang siap baik secara fisik, motif, tujuan, keterampilan dan pengetahuan untuk memberikan ASI Eksklusif setelah bayi lahir. Adapun salah satu cara untuk meningkatkan kesiapan ibu hamil dalam pemberian ASI Eksklusif, yaitu dengan memberikan penyuluhan kesehatan berupa "POSFLIP ASI" (Poster Flipchart Air Susu Ibu) yang berisi tentang ASI Eksklusif (pengertian ASI Ekskl usif, manfaat ASI Eksklusif, teknik dan posisi menyusui serta kandungan yang terdapat dalam ASI Eksklusif). Hal ini sesuai dengan hasil penelitian menurut Suhertusi, dkk (2014) bahwa ada pengaruh penyuluhan kesehatan terhadap pengetahuan yang dibuktikan dengan adanya peningkatan sebelum dan sesudah penyuluhan kesehatan dengan media leaflet dan film. Menurut Widha Ayu, dkk (2014) menunjukkan bahwa terdapat pengaruh penyuluhan terhadap tingkat pengetahuan dan sikap ibu menyusui dalam pemberian ASI eksklusif. Selain itu diketahui pula perbedaan pengetahuan dan sikap ibu menyusui tentang ASI eksklusif

hasil perbedaan kesiapan ibu hamil pada kelompok intervensi (pre-post test) kelompok kontrol (pre-post test) dengan p-value 0,000. Hal ini menunjukan hasil uji berpasangan untuk perbedaan antara kelompok intervensi (pre-post test) dan kelompok kontrol (pre-post test) didapatkan $\mathrm{p}$-value $<\alpha 0,05$ yang berarti Ha diterima, maka dapat disimpulkan bahwa terdapat perbedaan kesiapan sebelum dan sesudah penyuluhan kesehatan serta mengalami peningkatan nilai rata-rata.

Kesiapan merupakan keseluruhan kondisi seseorang yang membuatnya siap untuk memberikan respon atau jawaban di dalam cara tertentu terhadap suatu situasi. Penyesuaian kondisi pada suatu saat akan berpengaruh atau kecenderungan untuk memberi respon (Slameto, 2010). Kesiapan juga merupakan kemampuan yang cukup baik fisik, mental. Kesiapan fisik berarti tenaga yang cukup dan kesehatan yang baik, sedangkan kesiapan mental berarti memiliki minat dan motivasi yang cukup untuk melakukan suatu kegiatan (Dalyono, 2005). Faktor yang dapat mempengaruhi kesiapan seseorang adalah kondisi fisik yang tidak kondusif , kondisi psikologis yang kurang baik dan kesiapan materiil (Darsono dan Djamarah 2002). Adapun kondisi kesiapan antara lain kondisi fisi, mental, emosional, kebutuhankebutuhan, motif, tujuan, keterampilan, pengetahuan dan pengertian (Slameto, 2010). 
JURNAL SEHAT MASADA VOLUME XIV NOMOR 1 Januari $2020 \quad$ ISSN : 1979-2344

Kesiapan yang digunakan dalam penelitian ini mencakup aspek kesiapan kondisi fisik, motif, tujuan, keterampilan dan pengetahuan. Kesiapan fisik dalam penelitian ini dilihat dari kesiapan fisik ibu dalam pemberian ASI Eksklusif (kondisi payudara, kondisi tubuh), kesiapan motif ini merupakan kesiapan yang memiliki dorongan atau keinginan ibu baik dorongan dari faktor internal (diri sendiri) ataupun dorongan eksternal (keluarga). Aspek kesiapan tujuan merupakan kesiapan ibu dalam memberikan ASI Eksklusif dimana ibu harus mengetahui tujuan dan maanfaat dari pemberian ASI Eksklusf ini, untuk kesiapan keterampilan dilihat dari teknik dan posisi ibu dalam menyusui dengan dilakukannya praktek menyusui agar ibu tahu dan kesiapan pengetahuan ini mencakup pengetahuan ibu mengenai ASI Eksklusif, karena sebelum memberikan ASI ibu harus tahu terlebih dahulu mengenai ASI Eksklusif.

Menurut hasil penelitian Riyan Rossalin, dkk (2014) di dapatkan hasil bahwa terdapat pebedaan antara kelompok intervensi dan kelompok kontrol sebelum dan sesudah dilakukan penyuluhan menggunakan leaflet. Hal ini sesuai dengan tabel 4.3 dimana terdapat perbedaan ketika sebelum dan sesudah penyuluhan kesehatan poster flipchart Air Susu Ibu. Karena dengan melakukan penyuluhan kesehatan memberikan dan meningkatkan pengetahuan, sikap, praktek baik individu, kelompok atau masyarakat dalam memelihara dan meningkatkan kesehatan mereka sendiri (Notoatmodjo, 2012).

Hasil analisis Uji Independent Sampel Ttest pada kelompok intervensi dan kelompok kontrol tabel 4.5 di peroleh perbedaan kesiapan ibu hamil antara kelompok intervensi dan kelompok control dengan p-value 0,417. Kesiapan dalam penelitian ini diartikan sebagai suatu kondisi ibu hamil yang siap baik secara fisik, motif, tujuan, keterampilan dan pengetahuan tentang pemerian ASI Eksklusif.

Sebagai pembanding dalam menentukan seberapa besar efektivitas penyuluhan kesehatan tersebut, digunakanlah kelompok intervensi yang dilakukan penyuluhan kesehatan dengan media poster flipchart dan kelompok kontrol yang dilakukan dengan media leaflet. Untuk mengetahui perbedaan kelompok intervensi dan kelompok kontrol dilakukan dengan uji independent sampel t-test dan di dapatkan hasil $p$-value 0,417 $(\mathrm{p}=0,05)$. Ada Efektivitas Penyuluhan Kesehatan "POSFLIP ASI" Terhadap Kesiapan Ibu Hamil Dalam Pemberian ASI Eksklusif Di Wilayah Kerja Puskesmas Arcamanaik Kota Bandung.

\section{KESIMPULAN}

1. Kesiapan ibu hamil sebelum dilakukan penyuluhan kesehatan POSFLIP ASI pada kelompok intervensi dan kelompok kontrol sebagian besar memiliki kesiapan yang baik dengan nilai rata-rata pada kelompok intervensi 61,93 dan 54,53 pada kelompok kontrol. 
2. Kesiapan ibu hamil sesudah dilakukan penyuluhan kesehatan POSFLIP ASI pada kelompok intervensi dan kelompok kontrol sebagian besar memiliki kesiapan yang baik dengan nilai rata-rata pada kelompok intervensi 72,07 dan 63,60 pada kelompok kontrol.

3. Perbedaan kesiapan ibu hamil sebelum dan sesudah dilakukan penyuluhan kesehatan POSFLIP ASI pada kelompok intervensi (pre-post test) dan kelompok kontrol (prepost test). Didapatkan $\mathrm{p}$-value 0,000 (pvalue $=0,05$ ) yang berarti Ha diterima, maka dapat disimpulkan bahwa terdapat perbedaan kesiapan sebelum dan sesudah penyuluhan kesehatan.

4. Hasil analisis Uji Independent Sampel Ttest pada kelompok intervensi dan kelompok kontrol di peroleh kesiapan ibu hamil dengan nilai p-value 0,417. Yang berarti Ho gagal ditolak artinya ada Efektivitas Penyuluhan Kesehatan "POSFLIP ASI" Terhadap Kesiapan Ibu Hamil Dalam Pemberian ASI Eksklusif Di Wilayah Kerja Puskesmas Cijagra Lama Kota Bandung

\section{SARAN}

1. Peneliti mengharapkan agar ibu hamil memiliki kesiapan pengetahuan dan keterampilan sebelum memberikan ASI Eksklusif kepada bayi agar bayi sehat dan terhidar penyakit

2. Puskesmas diharapkan selalu memberikan edukasi kesehatan juga kepada ibu hamil trimester ke 3 tidak hanya kepada ibu menyusui saja, agar ibu selalu memberikan ASI secara Ekslusif dan nutrisi bayi terpenuhi.

\section{DAFTAR PUSTAKA}

Ayu, W.R.M, Mardji \& Devi, M. (2014) Pengaruh Penyuluhan ASI Eksklusif Terhadap Pengetahuan Ibu Tentang ASI Eksklusif Dan Sikap Ibu Menyusui Di Kecamatan Kanigoro Kabupaten Blitar. Jurnal Kejuruan. Vol. 37. No. 1,

Hidayat, A.A. 2013. Metode Penelitian Keperawatan dan Teknik Analisa Data. Salemba Medika.

Kholid, A. (2014). Promosi Kesehatan Dengan Pendekatan Teori Perilaku, Media Dan Aplikasinya. Jakarta: Rajawali Pers.

Maryuni, A. (2012). Inisiasi Menyusui Dini ASI Eksklusif dan Manejemen Laktasi. Jakarta: Trans Info Media.

ר__ (2015). Inisiasi Menyusui Dini ASI Eksklusif dan Manejemen Laktasi. Jakarta: Trans Info Media.

Marzida, D. P. (2016). Kesiapan Ibu hamil Dalam Pemberian ASI Eksklusif. Jurnal Kesehatan. Vol 7. No 2.

Rossalin,R, Mahyudin, Murtilita. (2014). Pengaruh Pendidikan Kesehatan Tentang Menyusui Eksklusif Terhadap Kesiapan Menyusui Pada Ibu Primigravida Dalam Memberikan ASI Eksklusif Di Wilayh Kerja Puskesmas Sungai Kelambu Kecamatan Tebas. 
JURNAL SEHAT MASADA VOLUME XIV NOMOR 1 Januari 2020 ISSN : 19792344 